\title{
Static lung volume should be used to confirm restrictive lung disease
}

\author{
This article was published in the following Dove Press journal: \\ International Journal of COPD \\ 8 September 2016 \\ Number of times this article has been viewed
}

\author{
Shweta A Rasam \\ Nitin V Vanjare \\ Department of Pulmonary Function \\ Laboratory, Chest Research \\ Foundation, Pune, Maharashtra, India
}

\section{Dear editor}

We read the study by Hee Jin Park et $\mathrm{al}^{1}$ with great interest. The authors have investigated the prevalence of comorbidities in Korean chronic obstructive pulmonary disease (COPD) population. We raise our concern regarding the definition of COPD in this study. The study defines COPD as airflow limitation (only pre-spirometry forced expiratory volume in 1 second/forced vital capacity $\left[\mathrm{FEV}_{1} / \mathrm{FVC}\right]<70 \%$ ) in subjects aged $\geq 40$ years. To differentiate, between asthma and COPD, it is essential to do a post bronchodilator spirometry. It would have been wise to report the findings as prevalence of comorbidities in obstructive airway diseases rather than specifically calling it as COPD.

In this study, the authors have compared the prevalence of comorbidities between three groups: normal, restrictive, and obstructive. There is a discrepancy in defining restriction on the basis of spirometry values. Here, restriction is defined as $\mathrm{FEV}_{1} / \mathrm{FVC}$ normal and $\mathrm{FEV}_{1}<80 \%$, but the actual criteria is $\mathrm{FVC}<80 \%$ predicted. However, it is important to note that restriction should be confirmed with static lung volumes rather than just relying on spirometry indices. Aaron et al have reported that out of the total number of subjects with low FVC on spirometry, only $41 \%$ had restriction when confirmed with lung volume measurements. ${ }^{2}$

It is likely that in this study restriction is overestimated due to the lack of static lung volume measurements. We assume that most of the subjects showing restriction on spirometry but otherwise having normal static lung volumes would have been then added to the normal group. Probably, this may have resulted in no significant differences in the comorbidities between the two groups (normal and obstructive). It would have been interesting to know the mean $\mathrm{FVC}$ and $\mathrm{FEV}_{1}$ values in the restrictive group. Apart from restriction, there are several reasons for reduced FVC. One of the reasons for reduced FVC in the restrictive group is obesity ${ }^{3}$ because $52.1 \%$ of the subjects in this group have body mass index (BMI) $\geq 23.0 \mathrm{~kg} / \mathrm{m}^{2}$.

The study concludes that hypertension is a common comorbidity in COPD compared to the normal group. However, this finding is confounded by factors such as age and sex. There is a significant difference in the mean age between normal and obstructive group. Anderson et al have reported that increased age is associated with significant increase in the prevalence of hypertension after 60 years of age. ${ }^{4}$ The male:female ratio is different in both the groups. There are more number of males in the obstructive group $(68 \%)$ as compared to normal (38.4\%). It is known that the incidence of hypertension is greater in men than that in women. ${ }^{5,6} \mathrm{~A}$ proper grouping, sex-, and age-matched analysis would have given a true estimate of the prevalence of comorbidities in different groups. 


\section{Disclosure}

The authors report no conflicts of interest in this communication.

\section{References}

1. Park HJ, Leem AY, Lee SH, et al. Comorbidities in obstructive lung disease in Korea: data from the fourth and fifth Korean National Health and Nutrition Examination Survey. Int J Chron Obstruct Pulmon Dis. 2015; 10:1571-1582.

2. Aaron SD, Dales RE, Cardinal P. How accurate is spirometry at predicting restrictive pulmonary impairment? Chest. 1999;115(3):869-873.
3. Zammit $\mathrm{C}$, Liddicoat $\mathrm{H}$, Moonsie I, Makker H. Obesity and respiratory diseases. Int J Gen Med. 2010;3:335-343.

4. Anderson GH. Effect of age on hypertension: analysis of over 4,800 referred hypertensive patients. Saudi J Kidney Dis Transpl. 1999;10(3): 286-297.

5. Anastos K, Charney P, Charon RA, et al. Hypertension in women: what is really known? The Women's Caucus, Working Group on Women's Health of the Society of General Internal Medicine. Ann Intern Med. 1991; 115(4):287-293.

6. Burt VL, Whelton P, Roccella EJ, et al. Prevalence of hypertension in the US adult population. Results from the Third National Health and Nutrition Examination Survey, 1988-1991. Hypertension. 1995;25(3): 305-313.

Dove Medical Press encourages responsible, free and frank academic debate. The content of the International Journal of Chronic Obstructive Pulmonary Disease 'letters to the editor' section does not necessarily represent the views of Dove Medical Press, its officers, agents, employees, related entities or the International Journal of Chronic Obstructive Pulmonary Disease editors. While all reasonable steps have been taken to confirm the content of each letter, Dove Medical Press accepts no liability in respect of the content of any letter, nor is it responsible for the content and accuracy of any letter to the editor.

\section{Publish your work in this journal}

The International Journal of COPD is an international, peer-reviewed journal of therapeutics and pharmacology focusing on concise rapid reporting of clinical studies and reviews in COPD. Special focus is given to the pathophysiological processes underlying the disease, intervention programs, patient focused education, and self management protocols.

\section{Dovepress}

This journal is indexed on PubMed Central, MedLine and CAS. The manuscript management system is completely online and includes a very quick and fair peer-review system, which is all easy to use. Visit http://www.dovepress.com/testimonials.php to read real quotes from published authors.

Submit your manuscript here: http://www.dovepress.com/international-journal-of-chronic-obstructive-pulmonary-disease-journal 